synonyms have been jettisoned and ignored almost from the moment of proposal, along with the invalid nominal genus. The prospect of family and superfamily names henceforth having to be altered so as to revive and immortalize invalid junior synonyms is as daunting as the prospect of the discreditable hunt that will be started among the literature, to be the first to unearth these corpses for revival.

If all palaeontologists who object to this clause becoming part of the Rules will write to the Secretary of the International Commission on Zoological Nomenclature, Mr. Francis Hemming, 28 Park Village East, Regent's Park, London, N.W. 1, let us hope that our protests may avail. (A copy of this letter is being sent him.) If any systematist feels that in an exceptional case it is desirable to retain a well-known family name based on an invalid synonym it is always open to him to apply for the protection of the Commission on behalf of that name. Otherwise, the Rules surely should state the obvious: namely, that the legitimate name of a family (or subfamily or superfamily) is that which is formed on the valid name of the type genus.

Sedgwick Museum,

W. J. Arkell. CAMBRIDGE.

7th February, 1954.

\title{
COMMENTS ON THE CARIBBEAN OLIGOCENE
}

SIR,--Dr. Eames's attempt (Geol. Mag., xc, 1953, pp. 388-392) to transfer half the Caribbean Oligocene into the Miocene is remarkable for the short list of references. The works of Caudri, Drooger, Grimsdale, Hedberg, Kugler, Olsson, Renz, Vaughan, and Woodring - to name but a few-should surely be considered before claiming flatly that Miogypsina indicates a Miocene age, regardless of other considerations.

A regional transgression can be recognized in the West Indies and in northern South America, Ecuador, and Peru. The transgressive beds are marked by the appearance of new faunal elements, which include ChattianRupelian molluscs ( fide Olsson, Rutsch, Woodring, et al.), and Oligocene larger foraminifera (fide Vaughan and collaborators, Caudri, et al.). The genus Miogypsina appears in the basal transgressive beds in several countries (Drooger, et al.), and its early forms appear to be a direct development from the Lower Oligocene Rotalia mexicana. The basal Camana unconformity in Southern Peru is a local example of the regional transgression: the presence of Miogypsina (Miolepidocyclina) ecuadorensis establishes correlation with beds in Ecuador, which themselves underlie thick pre-Aquitanian shales. Hence the basal Camana beds are Oligocene and Eames's claim (op. cit.) of a Miocene age is unacceptable.

Between the time of the mid-Oligocene transgression and the first appearance of faunas of Aquitanian type, the planktonic foraminifera show a welldefined pattern of change and evolution, consistent over the whole midAmerican region. Globigerina dissimilis survived for a short time. Near its evel of extinction the genus Globigerinatella made a short-lived appearance. The Globorotalia fohsi clan appeared, with an evolutionary sequence of subspecies, but died out abruptly as $G$. menardii appeared. Orbulina universa was preceded by its ancestral form $O$. suturalis.

European paleontologists could make an invaluable contribution to transoceanic Tertiary correlation by following Colom, Grimsdale, and others in recording the ranges of these species in the European Tertiaries.

c/o International Petroleum Co.,

R. M. Stainforth.

Talara, Peru.

9th February, 1954. 


\section{Selected References}

Barker, R. W., and Grimsdale, T. F., 1937. Studies of Mexican fossil foraminifera. Ann. Mag. Nat. Hist., ser. 10, xix, 161.

Bolli, H., 1950. The direction of coiling in the evolution of some Globorotaliidae. Contr. Cushman Found. Foram. Res., i, 82-9.

Bronnimann, P., 1951. The genus Orbulina d'Orbigny in the Oligo-Miocene of Trinidad, B.W.I. Contr. Cushman Found. Foram. Res., ii, 131-8.

Colom, G., and Gamundi, J., 1951. Sobre la extensión e importancia de las "Moronitas" a lo largo de las formaciones aquitano-burdigalienses del estrecho nort-bético. Inst. " Lucas Mallada" Invest. Geol., Estudios Geológicos, xiv, 331-385. Madrid.

Drooger, C. W., 1952. Study of American Miogypsinidae. Thesis, RijksUniv. Utrecht. Vonk and Co., Zeist, Netherlands.

Grimsdale, T. F., 1951. Correlation, age-determination, and the Tertiary pelagic foraminifera. Proc. Third World Petr. Congr., sec. 1, 463472.

Hedberg, H. D., 1937. Foraminifera of the Middle Tertiary Carapita formation of north-eastern Venezuela. Journ. Paleont., xi, 661-697.

Olsson, A. A., 1932. Contributions to the Tertiary paleontology of Peru: part 4, the Peruvian Oligocene. Bull. Amer. Pal., xix, no. 68.

Renz, H. H., 1942. Stratigraphy of northern South America, Trinidad, and Barbados. Proc. 8th Amer. Sci. "Congr., iv, 513-571.

1948. Stratigraphy and fauna of the Agua Salada group, State of Falcón, Venezuela. Geol. Soc. Amer., mem. xxxii.

Vaughan, T. W., and Cole, W. S., 1941. Preliminary report on the Cretaceous and Tertiary large foraminifera of Trinidad, B.W.I. Geol. Soc. Amer., Special Paper xxx.

WoOdRING, W.P., and ThOMPSON, T. F., 1949. Tertiary formations of Panama Canal Zone and adjoining parts of Panamá. Bull. Amer. Ass. Petr. Geol., xxxiii, 223-247.

\section{PUBLICATIONS RECEIVED}

Carte géologique de la Nouvelle-Calédonie à l'échelle de $100,000^{\circ}$ Feuille no. 1; Arama-Poum. Ministère de la France d'Outre-Mer, Paris (20 rue Monsieur, $7^{\mathrm{e}}$ ), 1953, price 1,200 francs metro. (The first of ten sheets covering New Caledonia.)

Géologie de la Région de Ponte Leccia (Corse), by J. F. Brondisk. Van Gorcum's Geologische Reeks, no. xvii; pp. 106, with 32 figs. and folding map in colour. Van Gorcum, Assen, 1954, price fl. 6.90 .

Catalogue of Type and Figured Specimens of Fossil Fishes and Amphibians in the Royal Scottish Museum, Edinburgh, by C. D. WATERston. Trans. Edinb. Geol. Soc., xvi, pt. 1, 1954 (91 pp.), price 7s. 6d.

Speleon. Tomo iv, no. 2, 1953. Universidad de Oviedo, Facultad de Ciencias (Instituto de Geologia, Oviedo).

Directory of Institutions engaged in Arid Zone Research. (Unesco publication.) H.M. Stationery Office, 1954,110 pp., price $8 s .6 d$.

The Geology of the Country about Coolgardie, Coolgardie Goldfield, W.A. Pt. 1, Regional Geology, by J. C. McMATH; pt. 2, Selected Mining Groups, by N. M. GRAY and H. J. WARD. Geol. Survey of Western Australia, Bull. 107, pp. 365, with figs. and folding maps (8vo), and supplementary atlas (foolscap); Perth, W.A., 1953.

Modern Science Illustrated: Astronomy, Biology, Chemistry, Physics, Geology. 448 pp., with numerous figures. Odhams Press, Ltd., 1954, price $25 s$. 